\title{
Evaluation of wild tomato accessions (Solanum spp.) for resistance to two-spotted spider mite (Tetranychus urticae Koch) based on trichome type and acylsugar content
}

\author{
Mohamed Rakha $\cdot$ Ndeye Bouba $\cdot$ \\ Srinivasan Ramasamy • Jean-Luc Regnard • \\ Peter Hanson
}

Received: 17 February 2016/ Accepted: 13 June 2016/Published online: 29 June 2016

(C) The Author(s) 2016. This article is published with open access at Springerlink.com

\begin{abstract}
Tomato wild relatives are important sources of resistance to many pests of cultivated tomato [Solanum lycopersicum L. (syn. Lycopersicon esculentum Mill.)]. Eleven wild tomato accessions previously identified at AVRDC-The World Vegetable Center as resistant to Bemisia tabaci were evaluated for resistance to the two-spotted spider mite [Tetranychus urticae (Koch.)] based on egg numbers using the leaf disc and Tanglefoot no-choice bioassays, and damage scores in choice bioassays. Highest resistance based on choice and no-choice bioassays was identified in AVRDC $S$. galapagense accessions VI057400, VI045262, VI037869 and VI037239, and S. cheesmaniae accession VI037240, all of which are new sources of $T$. urticae resistance. In addition, $S$. pimpinellifolium accession VI030462 exhibited resistance only in the no-choice bioassay based on egg
\end{abstract}

Mohamed Rakha and Ndeye Bouba have contributed equally to this work.

M. Rakha ( $\varangle)$. S. Ramasamy · P. Hanson

World Vegetable Center,

PO Box 42, Shanhua, Tainan 74199, Taiwan

e-mail: mohamed.rakha@worldveg.org

M. Rakha

Horticulture Department, Faculty of Agriculture,

Kafrelsheikh University, Kafr El-Sheikh 33516, Egypt

N. Bouba $\cdot$ J.-L. Regnard

Montpellier SupAgro, UMR AGAP 1334, TA-A-108/03,

Av. Agropolis, 34398 Montpellier Cedex 5, France numbers. Resistance to T. urticae based on the number of eggs from the no-choice bioassays was positively correlated with density of type IV glandular trichomes and negatively correlated with densities of type $\mathrm{V}$ trichomes. All resistant accessions accumulated high levels of total acylsugars, which were positively associated with type IV trichomes. There was a significant negative relationship between acylsugar content and T. urticae egg numbers from the no-choice bioassays. There was high correlation between the results from the leaf disc test and the Tanglefoot nochoice bioassay. These findings support the possible presence of broad-based insect and mite resistance in accessions closely related to cultivated tomato.

Keywords Insect resistance $\cdot$ Solanum cheesmaniae $\cdot$ S. galapagense $\cdot$ S. pimpinellifolium . Trichomes

\section{Introduction}

Tomato (Solanum lycopersicum L.) is widely grown and one of the most economically important vegetable crops worldwide (FAO 2015). The cultivated tomato is a host for many pathogens and pests. The two-spotted spider mite (Tetranychus urticae Koch (Acari: Tetranychidae) is a cosmopolitan agricultural pest, feeding on more than 140 different plant families and 1100 plant species including tomato (Dermauw 
et al. 2012). Warm, dry conditions favor rapid spider mite population build-up and increased feeding which, if uncontrolled, causes severe yield losses up to $90 \%$ in greenhouse and open field tomato crops in Southeast and West Africa (Sibanda et al. 2000). Spider mites feed by inserting their stylets into the leaf tissue and removing cell contents; the loss of leaf chlorophyll and the subsequent reduction in net photosynthetic rate causes leaf discoloration often called bronzing, a decline in overall plant health, or even death (Sances et al. 1981; Tomczyk and Kropczynska 1985; Park and Lee 2002). Spider mites can feed directly on fruit at mature green and breaker stages, and this damage can increase unmarketable fruit and economic losses (Ghidiu et al. 2006). Biological control of spider mites through natural enemies has only been widely practiced in closed greenhouses (Perdikis et al. 2008). Current spider mite control relies mainly on frequent applications of synthetic acaricides. However, spider mites have the capacity to quickly develop acaricide resistance (Van Leeuwen et al. 2004; Dermauw et al. 2012). Many aspects of spider mite biology, including rapid development, high reproductive ability of up to 25 generations per year, and haplo-diploid sex determination facilitate rapid evolution of pesticide resistance (Khajehali et al. 2011). Unfortunately, there are no tomato cultivars with resistance to spider mite. Identification of resistance sources and development of rapid screening methods are the first steps toward the development of spider mite resistant cultivars.

Resistance to spider mite and other insects has been found in some accessions of wild tomato species particularly S. habrochaites Knapp et Spooner (syn. Lycopersicon hirsutum Dunal), and S. pennellii Correll (syn. L. pennellii (Correll) d' Arcy) (de Azevedo et al. 2003; Resende et al. 2006). The resistance in these species was related to the presence of glandular trichomes (Frelichowski and Juvik 2001; Muigai et al. 2002; Oriani et al. 2011; Bleeker et al. 2012), which are reported to be absent in cultivated tomato (Luckwill 1943; Antonious 2001). Trichomes are considered the most important factor conferring pest resistance. The genus Solanum possesses seven types of trichomes of which types II, III and V are non-glandular, and types I, IV, VI and VII are glandular (Gurr and McGrath 2001; Simmons and Gurr 2005). Glandular trichomes secrete secondary metabolites including acylsugars, methylketones and sesquiterpenes that can be toxic, repellent, trap insects or act as a physical barrier, and interfere with insect feeding and oviposition (Dimock and Kennedy 1983; Snyder and Carter 1984; Channaryappa et al. 1992; Sharma et al. 2009).

Recent studies of wild relatives closely related to tomato found Bemisia tabaci resistance in some accessions of $S$. cheesmaniae (L. Riley) Fosberg (formerly L. cheesmaniae L. Riley), S. galapagense S. C. Darwin et Peralta (formerly L. cheesmaniae f. minor (Hook. f.) C. H. Müll.) and S. pimpinellifolium L. (formerly L. pimpinellifolium (L.) Mill.) (Firdaus et al. 2012, Lucatti et al. 2013, Rakha et al. 2015), all of which can be easily crossed with $S$. lycopersicum (Rick 1971; Peralta et al. 2008). Furthermore, $S$. pimpinellifolium accession TO-937 provided acceptable resistance to $T$. urticae (Fernández-Muñoz et al. 2000). Eleven wild tomato accessions including $S$. cheesmaniae, S. galapagense, and S. pimpinellifolium were previously identified at AVRDC-The World Vegetable Center as resistant to B. tabaci (Rakha et al. 2015). Identification of additional insect resistance in some or all these accessions would help to prioritize accessions for breeding cultivars with broad pest resistance. The objectives of this study were to evaluate selected whitefly-resistant accessions identified at AVRDC for spider mite resistance, assess whether trichomes and total acylsugars were related to mite resistance, and evaluate different spider mite screening methods for efficiency and accuracy.

\section{Materials and methods}

Plant materials

Eleven accessions including $S$. galapagense, $S$. cheesmaniae, and $S$. pimpinellifolium and a susceptible tomato check ( $S$. lycopersicum) were evaluated in greenhouse assays (Table 1). In a previous work (Rakha et al. 2015), these accessions were classified as abundant or sparse for type IV trichomes and evaluated for whitefly resistance based on number of adults, eggs, nymphs, and pupa from choice bioassays, and for adult mortality and egg number in no-choice bioassays (Rakha et al. 2015). Ten of these accessions exhibited high whitefly resistance, except $S$. cheesmaniae VI037238. AVRDC tomato line CL591593D4-1-0-3 (CL5915) was included as a spider mite susceptible check. Seeds of accessions were obtained from the AVRDC Genetic Resources and Seed Unit 
Table 1 Mean numbers of T. urticae eggs on wild tomato accessions compared to the tomato check CL5915 evaluated in Tanglefoot and leaf disc nochoice bioassays
Means followed by different letters within columns are different according to least significant difference (LSD) test at $p=0.05$

\begin{tabular}{|c|c|c|c|c|}
\hline \multirow[t]{3}{*}{ Taxa and AVRDC accessions code } & \multirow[t]{3}{*}{ Other codes } & \multicolumn{2}{|c|}{ Tanglefoot test } & \multirow{3}{*}{$\begin{array}{l}\text { Leaf disc test } \\
\text { Eggs (no.)/female } \\
\text { Abaxial }\end{array}$} \\
\hline & & \multicolumn{2}{|c|}{ Eggs (no.)/10 females } & \\
\hline & & Abaxial & Adaxial & \\
\hline \multicolumn{5}{|l|}{ Solanum galapagense } \\
\hline VI057400 & LA 483 & $0.0 \mathrm{~b}$ & $1.7 \mathrm{~cd}$ & $0.1 \mathrm{c}$ \\
\hline VI045262 & LA 1141 & $0.0 \mathrm{~b}$ & $4.0 \mathrm{bcd}$ & $0.2 \mathrm{c}$ \\
\hline VI037869 & LA 1408 & $0.0 \mathrm{~b}$ & $5.3 \mathrm{bcd}$ & $0.3 \mathrm{c}$ \\
\hline VI037239 & LA 436 & $0.0 \mathrm{~b}$ & $7.0 \mathrm{bc}$ & $0.3 \mathrm{c}$ \\
\hline VI063177 & LA 0530 & $1.0 \mathrm{~b}$ & $6.3 \mathrm{bcd}$ & $0.3 \mathrm{c}$ \\
\hline VI037241 & LA 526 & $0.2 \mathrm{~b}$ & $7.0 \mathrm{bc}$ & $0.5 \mathrm{c}$ \\
\hline VI063174 & LA 0438 & $0.2 \mathrm{~b}$ & $10.2 \mathrm{~b}$ & $0.9 \mathrm{c}$ \\
\hline VI037340 & LA 1408 & $0.8 \mathrm{~b}$ & $9.8 \mathrm{~b}$ & $0.7 \mathrm{c}$ \\
\hline \multicolumn{5}{|l|}{ Solanum cheesmaniae } \\
\hline VI037240 & LA 483 & $0.0 \mathrm{~b}$ & $0.0 \mathrm{~d}$ & $0.2 \mathrm{c}$ \\
\hline VI037238 & LA 429 & $20.0 \mathrm{a}$ & $17.5 \mathrm{a}$ & $8.2 \mathrm{a}$ \\
\hline \multicolumn{5}{|l|}{ Solanum pimpinellifolium } \\
\hline VI030462 & PI 390519 & $0.0 \mathrm{~b}$ & $6.6 \mathrm{bc}$ & $0.3 \mathrm{c}$ \\
\hline \multicolumn{5}{|l|}{ Solanum lycopersicum } \\
\hline CL5915 & & $20.0 \mathrm{a}$ & $21.6 \mathrm{a}$ & $5.1 \mathrm{~b}$ \\
\hline
\end{tabular}

(GRSU). Accessions and check were first tested in nochoice and later in choice spider mite bioassays at AVRDC.

\section{Spider mite bioassays}

The two-spotted spider mite (T. urticae) colony multiplied for choice and no-choice bioassays was kindly provided by the Tainan District Agricultural Research and Extension Station. The colony was reared and maintained on 2-3-week-old bean (Phaseolus vulgaris $\mathrm{L}$.) plants in a growth room at $23-30{ }^{\circ} \mathrm{C}$. Bean plants were replaced every 10 days by cutting an infested plant and placing it on top of a new plant for several days to allow spider mites to move onto the new plants. Adult female spider mites were transferred by fine brush onto new bean plants and allowed to oviposit. Two days after infestation, all mites were removed from the bean leaf and the deposited eggs hatched to become first-generation adults after approximately 10 days. Two-day-old female spider mites were used for no-choice bioassays.

No-choice bioassays were carried out in April and May 2015 using Tanglefoot tests (East et al. 1992) and leaf disc tests (Bleeker et al. 2012). Seed was sown in $14 \mathrm{~cm}$ pots with potting soil in an AVRDC greenhouse
(26 $\pm 4{ }^{\circ} \mathrm{C}, 10 / 14 \mathrm{~h}$ day/night). Plants were watered daily and fertilized weekly with NPK 15-15-15. Five weeks after sowing, five seedlings per accession and the susceptible check were moved from the plastic house to growth rooms. Plants were arranged following a completely randomized design with one plant per experimental unit. The experiment was conducted on stainless steel benches with 18 plants (two rows of nine plants) on each bench. Plant spacing was $20 \mathrm{~cm}$ between and within accessions. The growth room temperature was decreased slowly from 30 to $26^{\circ} \mathrm{C}$ to allow plants to adjust to the lower optimal temperatures $\left(26 \pm 2{ }^{\circ} \mathrm{C}\right)$ and conditions $(70 \% \mathrm{RH}$, $16 / 8 \mathrm{~h}$ day/night) for spider mites. For the Tanglefoot tests, plants were infested with spider mites 6 weeks after sowing. Ten female mites were placed on the adaxial side of the lateral leaflet of the third leaf from the apex of each plant. Mites were prevented from escaping from the leaflet by a band of Tanglefoot (Tanglefoot Co., Grand Rapids, Michigan, USA) according to the method described by East et al. (1992). All plants were inspected twice daily to ensure no leaflets touched the surface, which would allow mites to escape from the leaf. Two days after infestation the number of eggs on the adaxial and abaxial leaflets were counted. The leaflets were cut 
from plants to facilitate egg counting under a Leica S8 APO stereo microscope $(10 \times)$. For leaf disc tests, two young leaflets at the 2nd and 3rd leaf from the apex were cut from each tested plant of the accessions and check. Two leaf discs were cut from the middle of each leaflet using a $25 \mathrm{~mm}$ diameter circular punch and placed on wet cotton in plastic boxes $(3 \mathrm{~cm}$ high and $6 \mathrm{~cm}$ wide, diameter $=6 \mathrm{~cm}$ ) with their abaxial side up. One female mite was placed on each leaf disk. Two days after infestation the number of eggs was counted on each leaf disc as described above.

Choice bioassays were carried out in June and July 2015 using seedling trays. Seed was sown in 72-plug seedling trays with $40 \mathrm{ml}$ peat moss per cell. The accessions and check were grown at $26 \pm 4{ }^{\circ} \mathrm{C}$, $6 / 18 \mathrm{~h}$ day/night and fertilized and watered as described above. Three weeks after sowing, ten seedlings per accession and 180 plants from the check were transplanted in small pots $(7 \mathrm{~cm})$. These plants were arranged according to a randomized complete block design in 35-plug seedling trays (5 rows $\times 7$ columns) with one plant per accession and 18 plants per check in each experimental unit. The 11 accessions were randomly assigned to cells of the 2nd and 4th rows, and the check CL5915 occupying the 1st, 3rd and 5th row of each tray, so that there were 29 plants per tray. The trays were moved from the plastic house to growth rooms. The growth room temperature was decreased slowly to the optimal temperatures for spider mite as described above. One week after moving to the growth rooms, the plants were covered by a net $\left(60 \mathrm{mesh} / \mathrm{cm}^{2}\right)$ and mass infested with a very high density of spider mites from bean leaves. Each plant was inoculated with about 100 to 150 spider mite adults, eggs and nymphs. When the bean leaves wilted the net was removed from the plants, because the spider mites had moved onto the tomato plants. Leaf damage was scored 5 days after spider mite infestation using a $0-3$ visual scale, where $0=$ no damage, $1=$ few small feeding patches $(<20 \%$ of leaf area); $2=$ large feeding patches (20-49\% of leaf area); $3=$ entire leaf with feeding marks $(\geq 50 \%$ of leaf area).

Trichome and acylsugar analyses

During the no-choice bioassays, plants were simultaneously assessed for trichome type and density using a Leica S8 APO stereo microscope $(10 \times)$. Densities were determined from the interior middle section of the abaxial and adaxial surfaces of the third leaf from the apex in the Tanglefoot tests. Trichome type classification was carried out according to Luckwill (1943) and determined by morphology and presence/ absence of trichome glands. The trichomes were identified and counted on a1 $\mathrm{mm}^{2}$ area.

The 11 accessions and control plants were tested for acylsugar content 8 weeks after sowing in the plants used for no-choice bioassays. Three samples of 3 lateral leaflets were taken from each plant, placed in polyethylene vials $(20 \mathrm{ml})$, and placed in a drying oven at $30{ }^{\circ} \mathrm{C}$ for 3 days. Fully dried leaf samples were washed with $3 \mathrm{ml}$ of methanol. Acylsugar levels in the rinsate were measured as described by Leckie et al. (2012), in which the Nelson reaction originally used to measure sugar was replaced by a modified peroxidase/glucose oxidase assay (Setter et al. 2001). This modified assay provides improved results and eliminates use of arsenic compounds. Total acylsugar data were reported as micromoles of acylsugars per gram of dried leaf tissue $(\mu \mathrm{mol} / \mathrm{g})$.

Statistical procedures were performed using the statistical software SAS (version 9.1; SAS Institute, Cary, NC). Egg numbers from the no-choice bioassay based on Tanglefoot and leaf disc tests were transformed by natural logarithm (1n) before analysis. Data of spider mite resistance parameters in both choice and no-choice bioassays, densities of type I, IV, V and VI trichomes, and acylsugar content were subjected to one-way analysis of variance (ANOVA) followed by a least significant difference (LSD) test $(p=0.05)$. Linear correlations were calculated among densities of type I, IV, V and VI trichomes, and the number of eggs in the no-choice bioassay based on the Tanglefoot test and acylsugar content.

\section{Results}

Spider mite resistance in no-choice and choice bioassays

Two types of no-choice tests, Tanglefoot and leaf disc, were used to screen tomato accessions for spider mite resistance. These accessions were compared to the susceptible control for the number of eggs 2 days after infestation (Table 1). The Tanglefoot test revealed highly significant differences between accessions and 
the check for number of eggs on the abaxial and adaxial leaf surfaces $(p<0.001)$. Eggs were deposited mostly on the adaxial surface except for $S$. cheesmaniae accession VI037238 and the susceptible check CL5915. Mean number of eggs on the abaxial and adaxial surfaces of leaflets increased 2 to 20 -fold on CL5915 and S. cheesmaniae accession VI037238 compared to all S. galapagense accessions, S. cheesmaniae accession VI037240 and S. pimpinellifolium accession VI030462. Interestingly, no eggs were found on the abaxial and adaxial surfaces of leaflets of S. cheesmaniae accession VI037240 and very few eggs were found on $S$. galapagense accession VI057400. All $S$. galapagense displayed significantly higher spider mite resistance compared to the susceptible check and egg number dropped to zero on the abaxial surface for four of eight $S$. galapagense accessions along with $S$. cheesmaniae accession VI037240 and $S$. pimpinellifolium accession VI030462. In the leaf disc test, highly significant differences between accessions and the check were found for egg number $(p<0.001)$. High levels of resistance were observed in all $S$. galapagense, $S$. cheesmaniae accession VI037240, and S. pimpinellifolium accession VI030462. Conversely, the number of eggs increased 5 to 55-fold on CL5915 and 8 to 88-fold on S. cheesmaniae accession VI037238, which were similar to results of the Tanglefoot test (Table 1). This was also evident from high correlations between the leaf disc and Tanglefoot tests $(r=0.92$ $p<0.0001$ for abaxial surface and $r=0.72$ $p<0.0001$ for adaxial surface).

Selected tomato accessions were evaluated for spider mite damage in the choice bioassay 5 days after infestation (Fig. 1). The ANOVA revealed highly significant differences among accessions and the check for the damage ( $p<0.001)$. All CL5915 plants, S. cheesmaniae accession VI037238, and S. pimpinellifolium accession VI030462 had severe damage. None of the accessions were immune to spider mite but all $S$. galapagense accessions and $S$. cheesmaniae accession VI037240 sustained significantly less damage than CL5915.

Trichome diversity and its relationship to spider mite resistance

Trichome types I, IV, V and VI in selected tomato accessions and the check were evaluated on both the abaxial and adaxial leaf surfaces in Tanglefoot tests; types II and III were ignored because they have not been associated with insect resistance. The analysis of variance revealed highly significant differences $(p<0.001)$ between accessions and the check for density of trichome types IV, V and VI (Table 2). Type IV trichomes were abundant on the abaxial and adaxial leaf surfaces of all $S$. galapagense accessions and $S$. cheesmaniae accession VI037240, whereas the check CL5915 and S. cheesmaniae accession VI037238 lacked type IV. Conversely, type V trichomes were absent in all $S$. galapagense accessions and $S$. cheesmaniae accession VI037240, whereas the check and S. cheesmaniae accession VI037238 contained relatively high densities of type $\mathrm{V}$ trichomes. It is noteworthy that type IV trichomes on S. pimpinellifolium accession VI030462 were low on the adaxial leaf surface but were relatively high on the abaxial surface. Most accessions were devoid of type VI trichomes or developed sparse densities of lobeshaped type VI trichomes; notably, S. pimpinellifolium accession VI30462 developed relatively high densities of spherical-shaped type VI trichomes. Type I trichomes were present on all accessions and the check, but uniformly low on the abaxial and adaxial leaf surfaces with a mean density rating of 1 . All resistant accessions produced high densities of type IV trichomes and no type $\mathrm{V}$ trichomes. Correlations were subjectively categorized as low $( \pm 0.18-0.30)$, moderate $( \pm 0.31-0.50)$, high $( \pm 0.51-0.75)$ and very high $( \pm \geq 0.76)$. Type IV trichome density was negatively correlated with egg number on both leaf surfaces. In contrast, significant positive correlations were detected between type $\mathrm{V}$ trichome density and number of eggs on both leaf surfaces. Furthermore, correlations between number of eggs on the abaxial and adaxial leaf surfaces and type I trichomes and type VI trichomes were either weakly statistically significant or not significant; only the correlation between number of eggs on the abaxial leaf surface showed a moderate negative correlation.

Acylsugar content and its relationship to spider mite resistance and trichomes

Large differences $(p<0.001)$ in total acylsugar content were found among accessions and the check (Fig. 2). All S. galapagense accessions accumulated 9 to 22-fold higher levels of acylsugars ( $\mu$ mol acylsugar/ 


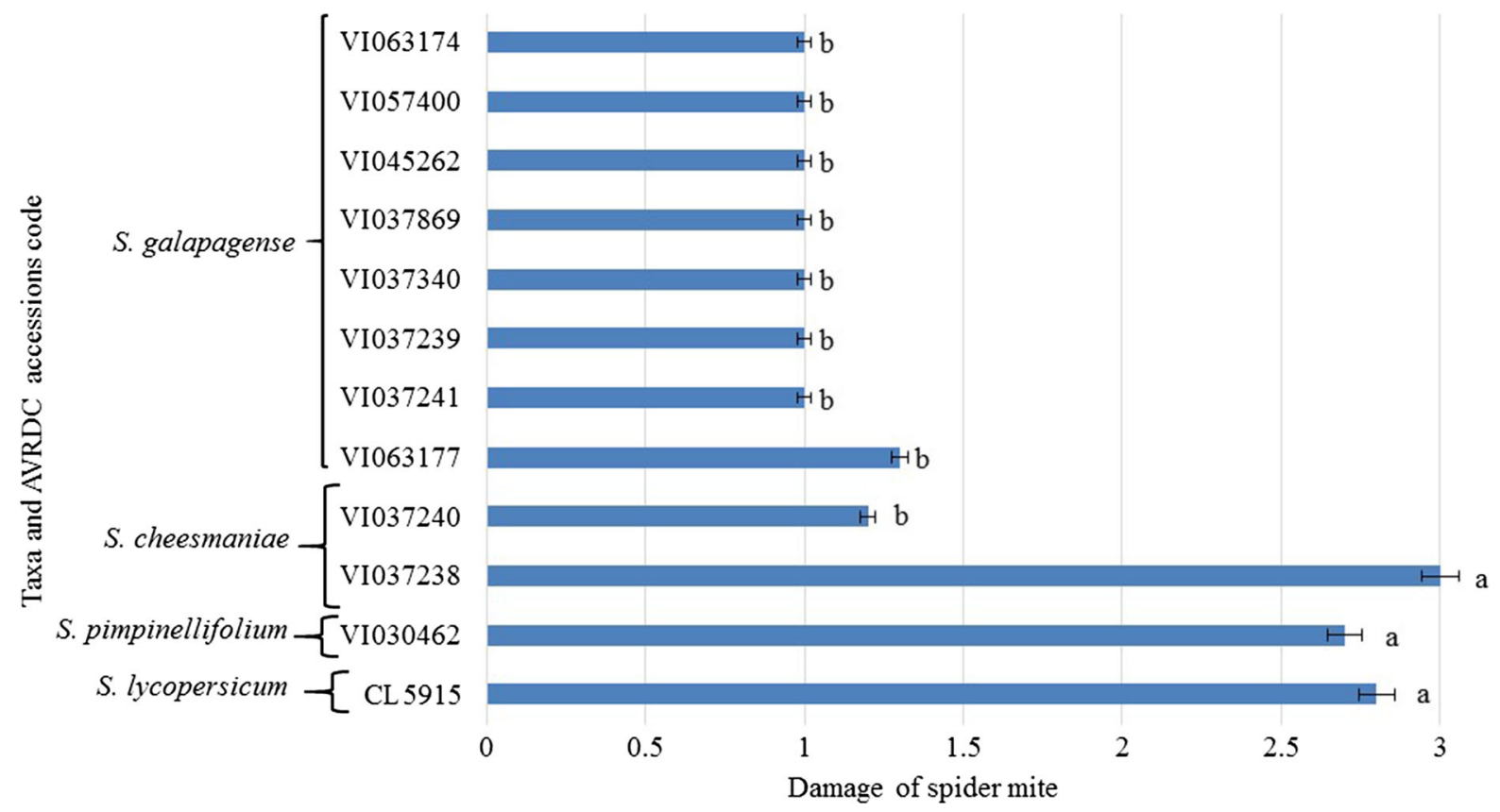

Fig. 1 Spider mite damage in selected wild tomato accessions (Solanum spp.) and tomato check (CL5915) in the growth room 5 days after spider mite infestation. Ratings assessed visually 5 days after spider mite infestation, and are based on the leaf damage using a $0-3$ scale, where $0=$ no damage, $1=$ few

g dry leaf tissue) compared to CL5915. Total acylsugar content in $S$. cheesmaniae accession VI037240 and $S$. pimpinellifolium accession VI030462 were also significantly greater (7 to 12 -fold increase) than the check. In contrast, CL5915 and $S$. cheesmaniae accession VI037238 accumulated low acylsugar levels $(<4.2 \mu \mathrm{mol}$ acylsugar/g dry leaf tissue). Correlation analysis indicated strong associations between acylsugar accumulation, spider mite resistance based on egg number, and trichome types. Highly significant negative correlations were obtained between total acylsugar content and number of eggs from the Tanglefoot test $(r=-0.73$ for abaxial surface and $r=-0.68$ for adaxial surface). Type IV trichome density on the abaxial and adaxial leaf surfaces was positively correlated with total acylsugar content (Table 3). Conversely, negative and highly significant correlations were found between type $\mathrm{V}$ trichome density on the abaxial and adaxial leaf surfaces and total acylsugar content (Table 3). Furthermore, correlations between acylsugar content and type I trichomes and type VI trichomes on the abaxial small feeding patches $(<20 \%$ of leaf area $) ; 2=$ large feeding patches $20-49 \%$ of leaf area; $3=$ entire leaf with feeding marks $(\geq 50 \%$ of leaf area). Mean $\pm \operatorname{SE}(n=10)$ followed by different letters are significantly different according to according to least significant difference (LSD) test at $p<0.05$

and adaxial leaf surfaces were either weakly statistically significant or not significant.

\section{Discussion}

The two spotted spider mite, T. urticae, is one of the most economically damaging pests of cultivated tomato, particularly in Southeast Africa, West Africa, South Asia, Southeast Asia, Europe and Mediterranean countries. Sustainable chemical control of spider mites is difficult because of its capacity to rapidly develop resistance to new acaricides (Dermauw et al. 2012). Spider mite resistant tomato cultivars, if available, would offer growers an inexpensive and easier method of pest control.

In general, some wild tomato species are far less attractive to pests than cultivated tomato due to their glandular trichomes and production of effective defense compounds. Most previous studies focused on identification of spider mite resistance from distant wild tomato species including accessions of $S$. 
Table 2 Mean numbers of trichome type densities on wild tomato accessions compared to the tomato check CL5915 evaluated in the Tanglefoot no-choice bioassay

\begin{tabular}{|c|c|c|c|c|c|c|c|c|c|}
\hline \multirow[t]{3}{*}{ Taxa and AVRDC accessions code } & \multirow{3}{*}{$\begin{array}{l}\text { Other } \\
\text { codes }\end{array}$} & \multicolumn{8}{|c|}{ Trichomes density $/ \mathrm{mm}^{2 \mathrm{z}}$} \\
\hline & & \multicolumn{2}{|l|}{ Type I } & \multicolumn{2}{|l|}{ Type IV } & \multicolumn{2}{|l|}{ Type V } & \multicolumn{2}{|l|}{ Type VI } \\
\hline & & Abaxial & Adaxial & Abaxial & Adaxial & Abaxial & Abaxial & Abaxial & Adaxial \\
\hline \multicolumn{10}{|l|}{ Solanum galapagense } \\
\hline VI057400 & LA 483 & 1.0 & 1.0 & $15.3 \mathrm{bc}$ & $11.0 \mathrm{ab}$ & $0.0 \mathrm{c}$ & $0.0 \mathrm{~d}$ & $2.3 \mathrm{bc}$ & $2.0 \mathrm{~cd}$ \\
\hline VI045262 & LA 1141 & 1.0 & 1.0 & $15.5 \mathrm{bc}$ & $10.3 \mathrm{ab}$ & $0.0 \mathrm{c}$ & $0.0 \mathrm{~d}$ & $2.3 \mathrm{bc}$ & $2.3 \mathrm{~cd}$ \\
\hline VI037869 & LA 1408 & 1.0 & 1.0 & $19.0 \mathrm{abc}$ & $12.8 \mathrm{a}$ & $0.0 \mathrm{c}$ & $0.0 \mathrm{~d}$ & $1.8 \mathrm{~cd}$ & $1.5 \mathrm{~cd}$ \\
\hline VI037239 & LA 436 & 1.0 & 1.0 & $16.0 \mathrm{bc}$ & $7.6 \mathrm{~b}$ & $0.0 \mathrm{c}$ & $0.0 \mathrm{~d}$ & $3.0 \mathrm{bc}$ & $3.8 \mathrm{bc}$ \\
\hline VI063177 & LA 0530 & 1.0 & 1.0 & $22.0 \mathrm{ab}$ & $10.0 \mathrm{ab}$ & $0.0 \mathrm{c}$ & $0.0 \mathrm{~d}$ & $2.3 \mathrm{bc}$ & $3.3 \mathrm{bc}$ \\
\hline VI037241 & LA 526 & 1.0 & 1.0 & $17.8 \mathrm{abc}$ & $8.6 \mathrm{ab}$ & $0.0 \mathrm{c}$ & $0.0 \mathrm{~d}$ & $2.6 \mathrm{bc}$ & $2.4 \mathrm{bcd}$ \\
\hline VI063174 & LA 0438 & 1.0 & 1.0 & $14.6 \mathrm{c}$ & $7.2 \mathrm{~b}$ & $0.0 \mathrm{c}$ & $0.0 \mathrm{~d}$ & $2.8 \mathrm{bc}$ & $3.4 \mathrm{bc}$ \\
\hline VI037340 & LA 1408 & 1.0 & 1.0 & $13.5 \mathrm{c}$ & $11.3 \mathrm{ab}$ & $0.0 \mathrm{c}$ & $0.0 \mathrm{~d}$ & $2.3 \mathrm{bc}$ & $1.8 \mathrm{~cd}$ \\
\hline \multicolumn{10}{|l|}{ Solanum cheesmaniae } \\
\hline VI037240 & LA 483 & 1.0 & 1.0 & $23.5 \mathrm{a}$ & $12.5 \mathrm{a}$ & $0.0 \mathrm{c}$ & $0.0 \mathrm{~d}$ & $4.5 \mathrm{~b}$ & $5.3 \mathrm{~b}$ \\
\hline VI037238 & LA 429 & 1.0 & 1.0 & $0.0 \mathrm{~d}$ & $0.0 \mathrm{c}$ & $5.0 \mathrm{~b}$ & $2.0 \mathrm{~b}$ & $0.0 \mathrm{~d}$ & $0.0 \mathrm{~d}$ \\
\hline \multicolumn{10}{|l|}{ Solanum pimpinellifolium } \\
\hline VI030462 & PI 390519 & 1.0 & 1.0 & $4.6 \mathrm{~d}$ & $1.4 \mathrm{c}$ & $1.0 \mathrm{c}$ & $1.0 \mathrm{c}$ & $8.2 \mathrm{a}$ & $8.8 \mathrm{a}$ \\
\hline \multicolumn{10}{|l|}{ Solanum lycopersicum } \\
\hline CL5915 & & 1.0 & 1.0 & $0.0 \mathrm{~d}$ & $0.0 \mathrm{c}$ & $9.0 \mathrm{a}$ & $5.0 \mathrm{a}$ & $3.4 \mathrm{bc}$ & $2.4 \mathrm{bcd}$ \\
\hline
\end{tabular}

Means followed by different letters within columns are different according to least significant difference (LSD) test at $p<0.05$

${ }^{\mathrm{z}}$ Type-trichome densities were evaluated in a $1 \mathrm{~mm}^{2}$ area during no-choice bioassay based on Tanglefoot method as described in Materials and Methods

habrochaites f. glabratum (PI 134417, PI 251304, PI 134418 and PI 126449), S. habrochaites (PI 127826, LA1777, LA 1740 and LA 2860) and S. pennellii (LA 716, LA 2963 and LA 2580) (Gentile et al. 1969; Snyder and Carter 1984; Antonious and Snyder 2006; Saeidi and Mallik 2006; Onyambus et al. 2011; Bleeker et al. 2012; Lucini et al. 2015). More than 250 wild tomato accessions were recently screened at AVRDC including $S$. galapagense, $S$. cheesmaniae and $S$. pimpinellifolium and high levels of whitefly $(B$. tabaci) resistance were identified in one or more accessions of each species (Rakha et al. 2015). These species are closely related to cultivated tomato and introgression of resistance into cultivated tomato from these species should be easier and faster compared to the green-fruited species S. pennellii, and S. habrochaites (Rick, 1971; Peralta et al. 2008).

In this study we evaluated the previously identified whitefly-resistant accessions of $S$. galapagense, S. cheesmaniae and S. pimpinellifolium for spider mite resistance based on oviposition in no-choice bioassays and damage scores in choice bioassays. The previous whitefly resistance study indicated resistance in these accessions was based on the presence of high densities of glandular type IV trichomes resulting in high foliar acylsugar content, and absence or low densities of type $\mathrm{V}$ trichomes. Our purpose was to determine if some or all of these accessions were also resistant to spider mite, and if this resistance was based on the same mechanisms. We found that most whitefly-resistant accessions were also resistant to spider mite, the most resistant accessions being $S$. galapagense VI057400, VI045262, VI037869 and VI037239, and S. cheesmaniae VI037240. To our knowledge, this is the first report of resistance to $T$. urticae in these accessions. Spider mite resistance in these accessions was expressed in early plant stages (4-6 weeks old) and resulted in relatively low leaf damage and egg number; early trichome development is advantageous because tomato seedlings are often 


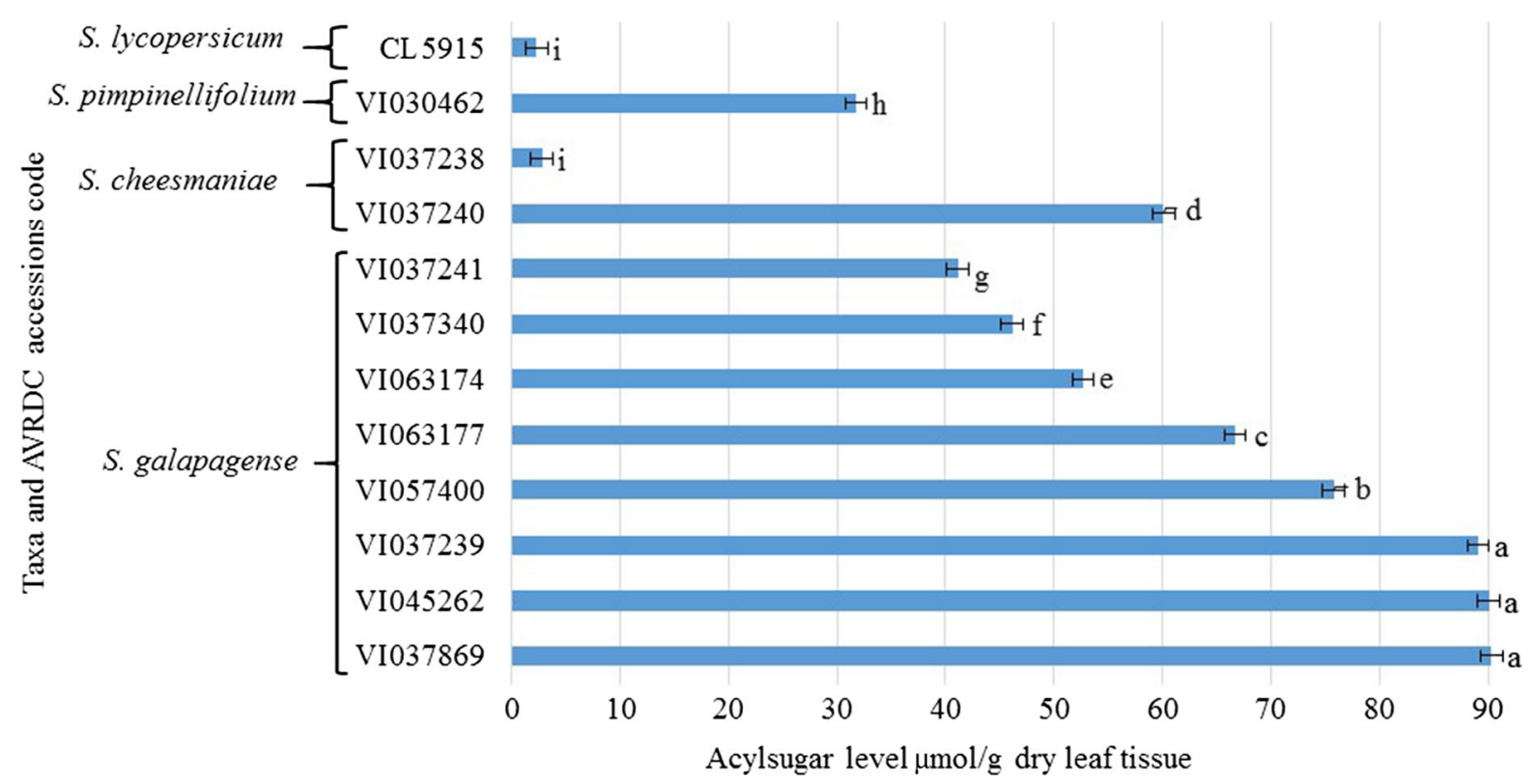

Fig. 2 Total acylsugars levels ( $\mu$ mol acylsugar/g dry leaf tissue) measured in selected wild tomato (Solanum spp.) accessions and tomato check (CL5915) 6 weeks after sowing.
Mean \pm SE $(n=5)$ followed by different letters according to least significant difference (LSD) test at $p<0.05$

Table 3 Linear correlations between trichome types, total acylsugar and T. urticae egg numbers of selected wild tomato accessions evaluated in the Tanglefoot no-choice bioassay

\begin{tabular}{|c|c|c|c|}
\hline \multirow[t]{2}{*}{ Trichomes density $/ \mathrm{mm}^{2 \mathrm{z}}$} & \multirow{2}{*}{$\begin{array}{l}\text { Total acylsugar } \\
(\mu \mathrm{mol} / \mathrm{g} \text { dry leaf tissue })\end{array}$} & \multicolumn{2}{|c|}{ Eggs $(\text { no. })^{\mathrm{y}}$} \\
\hline & & Adaxial & Abaxial \\
\hline Type I (adaxial) & $0.00^{\mathrm{ns}}$ & $-0.00^{\mathrm{ns}}$ & $-0.00^{\mathrm{ns}}$ \\
\hline Type I (abaxial) & $0.08^{\mathrm{ns}}$ & $-0.25^{\mathrm{ns}}$ & $-0.06^{\mathrm{ns}}$ \\
\hline Type IV (adaxial) & $0.68 * *$ & $-0.57 * *$ & $-0.64 * *$ \\
\hline Type IV (abaxial) & $0.69 * *$ & $-0.55^{* *}$ & $-0.69 * *$ \\
\hline Type V (adaxial) & $-0.71 * *$ & $0.52 * *$ & $0.87 * *$ \\
\hline Type V (abaxial) & $-0.68 * *$ & $0.53 * *$ & $0.87 * *$ \\
\hline Type VI (adaxial) & $0.04^{\mathrm{ns}}$ & $-0.09^{\mathrm{ns}}$ & $-0.33^{*}$ \\
\hline Type VI (abaxial) & $0.05^{\mathrm{ns}}$ & $-0.13^{\mathrm{ns}}$ & $-0.25^{\mathrm{ns}}$ \\
\hline
\end{tabular}

ns Indicates not significant

${ }^{\mathrm{z}}$ Type-trichome densities were evaluated in a $1 \mathrm{~mm}^{2}$ area during no-choice bioassay by Tanglefoot method as described in Materials and Methods

y $T$. urticae egg numbers were counted on the abaxial and adaxial leaf surfaces of selected wild tomato accessions evaluated in nochoice bioassay by Tanglefoot method

$*, * *$ Indicate significance at $p<0.05$ and $p<0.001$, respectively

exposed to spider mite infestation in greenhouses before field transplanting. Fortunately, densities of glandular trichomes also increased with the plant age (data not shown) on resistant accessions.
We found high densities of type IV trichomes and acylsugar content in the $S$. galapagense accessions (VI057400, VI045262, VI037869 and VI037239) and S. cheesmaniae accession VI037240. The reduction in 
egg number in the no-choice bioassay was highly correlated with high densities of type IV trichomes and total acylsugar content, suggesting the presence of host non-preference (antixenosis) and/or preference (antibiosis). All released adult females on these accessions stuck on the sticky exudate from glandular trichomes on the adaxial leaf surface and died (data not shown). This exudate blocked the mobility of the spider mites on the leaf surface to crawl from leaf to leaf (Van Haren et al. 1987; Lucini et al. 2015). Ample evidence links glandular trichomes, acylsugars and resistance to many arthropod pests including spider mite (Good and Snyder 1988; Maluf et al. 2007; Saeidi et al. 2007; Onyambus et al. 2011; Lucini et al. 2015), whitefly (Firdaus et al. 2012, Lucatti et al. 2013) and other arthropod pests (Maluf et al. 2001; Resende et al. 2006). Foliar application of acylsugars from $S$. pennellii LA716 reduces feeding of aphids Myzus persicae and Macrosiphum euphorbiae (Goffreda et al. 1989; Rodriguez et al. 1993) and sharply reduced oviposition and feeding of the leafminer, Liriomyza trifolii (Hawthorne et al. 1992) and whitefly, B. tabaci (Liedl et al. 1995). Lucini et al. (2015) also showed that acylsugars hampered the mobility of the mite on the leaf surface, ultimately causing death. It is highly likely that acylsugars accounted entirely or partly for the spider mite resistance in the $S$. galapagense accessions. The production of acylsugars and determination of acylsugar composition in tomato is a complex trait involving many loci. Previous research has identified multiple QTL associated with acylsugar production in populations derived from $S$. pennellii LA716 (Liedl et al. 1995; Leckie et al. 2012). It is noteworthy that $S$. cheesmaniae accession VI037240 developed similar densities of type IV trichomes but accumulated much less acylsugars per gram of dry leaf tissue than the $S$. galapagense accessions. Lucatti et al. (2013) also confirmed that $S$. galapagense accessions in general accumulate higher levels of acylsugars than S. cheesmaniae accessions. Thus, the presence of high type IV trichome numbers does not necessarily result in high acylsugars. S. pimpinellifolium accession VI030462 exhibited resistance in the no-choice bioassay based on the number of eggs, whereas the same accession was severely damaged in the choice bioassay. The low density of type IV trichomes on the adaxial leaf surface could explain the severe damage observed on this accession in the choice bioassay. However, most of the mites that fed on this accession eventually died (data not shown), which could be due to the presence of some specific toxic compound(s) in or on VI030462 leaves that cause antibiosis. Only VI030462 developed a high density of sphericalshaped type VI trichomes while the other accessions had lobe-shaped type VI trichomes. Differences in type VI trichome shape may be related with differences in the kinds and concentrations of chemicals associated with insect resistance. Ben-Israel et al. (2009) found that spherical-shaped type VI trichomes accumulated higher concentrations of methylketone compared to lobe-shaped type VI trichomes in $\mathrm{F}_{2}$ interspecific populations derived from $S$. habrochaites f. glabratum C. H. Müll. Similar associations were found between the presence of spherical-shaped type VI trichomes and whitefly resistance of VI030462 based on numbers of whitefly adults, nymphs, pupa, and eggs in the choice bioassay, and adult mortality and number of eggs from the no-choice bioassays (Rakha et al. 2015), suggesting the presence of similar mechanisms of resistance to spider mite and whitefly in this accession. Besides high type IV trichome density, whitefly resistance has been associated with sparsity or absence of type $\mathrm{V}$ trichomes (Butter and Vir 1989; Firdaus et al. 2012; Lucatti et al. 2013; Rakha et al. 2015). In this study only the susceptible check and one $S$. cheesmaniae accession, VI037238, produced type $\mathrm{V}$ trichomes, so the relationship of type $\mathrm{V}$ trichomes to spider mite resistance cannot be assessed here. In this study, type VI trichomes were not correlated with spider mite resistance, which agrees with the findings of Good and Snyder (1988) and Onyambus et al. (2011).

Leaf disc techniques frequently have been used to screen for spider mite resistance on tomato (Onyambus et al. 2011; Bleeker et al. 2012), strawberry (Giménez-Ferrer et al. 1993) and muskmelon (East et al. 1992). We found high and significant correlations between results of the leaf disc and Tanglefoot tests in the no-choice bioassay, indicating that the leaf disc test provided equivalent results. Tanglefoot tests were used successfully to screen spider mite resistance in muskmelon (East et al. 1992), but this method is very time consuming, labor intensive and not easily applicable to screening large plant populations. Compared to the Tanglefoot test, leaf disc tests are easier to conduct under controlled conditions and a small growth room is sufficient to screen large numbers of accessions/populations. An additional advantage of 
the leaf disc is the option to carry out the test in a choice situation for spider mite resistance as described by Bleeker et al. (2012). Similar results from in vitro leaf disc tests and in vivo no-choice tests were observed in whitefly (Firdaus et al. 2012) and thrips resistance assessments (Maharijaya et al. 2011).

It is possible that the identified whitefly/spider mite-resistant accessions could offer resistance to other important tomato pests and future studies are planned to assess their resistance to South American tomato leafminer, (Tuta absoluta), other leafminer species (e.g. L. trifolii), tomato fruit worm (Helicoverpa armigera) and armyworm (Spodoptera litura). Resistance to each insect may depend on the susceptibility of the targeted insect to acylsugars and the levels and types of acylsugars produced, presence of other, non-acylsugar based insect resistance, glandular trichomes, coverage of foliar tissue (abaxial and adaxial leaf surfaces), effects of plant age, temperature, light intensity and other environmental factors on accumulation of acylsugars (Gurr and McGrath 2001; Kang et al. 2010, Lucatti et al. 2013; Puentes and Ågren, 2013). Although breeders would be interested to know the minimum acylsugar levels required for spider mite resistance, these cannot be determined from this study. Answers to these questions will inform decisions on the choice of accessions to introgress resistance and overall insect resistance strategies.

Acknowledgments We thank Grace Hsu for acylsugar analysis, Su Fu-cheng for rearing spider mites, and Maureen Mecozzi for editing the manuscript. Financial support from the AVRDC Innovations Fund is gratefully acknowledged. Core funding to support AVRDC activities worldwide is provided by the Republic of China (ROC), UK Department for International Development (UK/DFID), United States Agency for International Development (USAID), Germany, Thailand, Philippines, Korea, and Japan.

\section{Compliance with ethical standards}

Conflict of interest The authors declare that they have no conflict of interest.

Open Access This article is distributed under the terms of the Creative Commons Attribution 4.0 International License (http:// creativecommons.org/licenses/by/4.0/), which permits unrestricted use, distribution, and reproduction in any medium, provided you give appropriate credit to the original author(s) and the source, provide a link to the Creative Commons license, and indicate if changes were made.

\section{References}

Antonious GF (2001) Production and quantification of methyl ketones in wild tomato accessions. J Environ Sci Health Part B 36:835-848

Antonious GF, Snyder JC (2006) Repellency and toxicity of wild tomato leaf extracts to two-spotted spider mite, $T e$ tranychus urticae Koch. J Environ Sci Health Nat Prod B 41:43-55

Ben-Israel I, Yu G, Austin MB, Bhuiyan N, Auldridge M, Nguyen T, Schauvinhold I, Noel JP, Pichersky E, Fridman E (2009) Multiple biochemical and morphological factors underlie the production of methylketones in tomato trichomes. Plant Physiol 151:1952-1964

Bleeker PM, Mirabellaa R, Diergaardeb PJ, VanDoornb A, Tissierc A, Kantd MR, Prinsb M, de Vosb M, Haringa MA, Schuurinka RC (2012) Improved herbivore resistance in cultivated tomato with the sesquiterpene biosynthetic pathway from a wild relative. Proc Natl Acad Sci USA 109(49):20124-20129

Butter NS, Vir BK (1989) Morphological basis of resistance in cotton to the whitefly Bemisia tabaci. Phytoparasitica 17(4):251-261

Channaryappa SG, Muniyappa V, Frist RH (1992) Resistance of Lycopersicon species to Bemisia tabaci, a tomato leaf curl virus vector. Can J Bot 70:2184-2192

de Azevedo SM, Faria MV, Maluf WR, de Oliveira ACB, de Freitas JA (2003) Zingiberene-mediated resistance to the South American tomato pinworm derived from Lycopersicon hirsutum f. hirsutum. Euphytica 134:347-351

Dermauw W, Ilias A, Riga M, Tsagkarakou A, Grbić M, Tirry L, Van Leeuwen T, Vontas J (2012) The cys-loop ligandgated ion channel gene family of Tetranychus urticae: implications for acaricide toxicology and a novel mutation associated with abamectin resistance. Insect Biochem Mol Biol 42(7):455-465

Dimock MB, Kennedy YG (1983) The role of glandular trichomes in the resistance of Lycopersicon hirsutum $\mathrm{f}$. glabratum to Heliothis zea. Entomol Exp Appl 33:263-268

East DA, Edelson JV, Cox EL, Harris MK (1992) Evaluation of screening methods and search for resistance in muskmelon, Cucumis melo L., to the two-spotted spider mite, Tetranychus urticae Koch. Crop Prot 11:39-44

FAO (2015) FAOSTAT Database on Production, FAO Statistics Division, Food and Agriculture Organization of the United Nations, Rome. Available online at http://faostat.fao.org/ site/339/default.aspx. Accessed 28 Aug 2015

Fernández-Muñoz R, Domínguez E, Cuartero J (2000) A novel source of resistance to the two-spotted spider mite in $L y$ copersicon pimpinellifolium (Jusl.) Mill.: its genetics as affected by interplot interference. Euphytica 111:169-173

Firdaus S, van Heusden A, Hidayati N, Supena ED, Visser RG, Vosman B (2012) Resistance to Bemisia tabaci in tomato wild relatives. Euphytica 187:31-45

Frelichowski JE, Juvik JA (2001) Sesquiterpene carboxylic acids from a wild tomato species affect larval feeding behavior and survival of Helicoverpa zea and Spodoptera exigua (Lepidoptera: Noctuidae). J Econ Entomol 94:1249-1259 
Gentile AG, Webb RE, Stoner AK (1969) Lycopersicon and Solanum spp. resistant to the carmine and two-spotted spider mite. J Econ Entomol 62:834-836

Ghidiu GM, Hitchner EM, Fburk JE (2006) Goldfleck damage to tomato fruit caused by feeding of Frankliniella occidentalis (Thysanoptera: Thripidae). Florida Entomol 89:279-281

Giménez-Ferrer RMG, Scheerens JC, Erb WA (1993) In vitro screening of 76 strawberry cultivars for two-spotted spider mite resistance. HortScience 28:841-844

Goffreda JC, Mutschler MA, Avé DA, Tingey WM, Steffens JC (1989) Aphid deterrence by glucose esters in the glandular exudate of the wild tomato, Lycopersicon pennellii. J Chem Ecol 15:2135-2147

Good DE, Snyder JC (1988) Seasonal variation of leaves and mite resistance of Lycopersicon interspecific hybrids. HortScience 23:891-894

Gurr GM, McGrath D (2001) Effect of plant variety, plant age and photoperiod on glandular pubescence and host-plant resistance to potato moth (Phthorimaea operculella) in Lycopersicon spp. Ann Appl Biol 138:221-223

Hawthorne DJ, Shapiro JA, Tingey WM, Mutschler MA (1992) Trichome-borne and artificially applied acylsugars of wild tomato deter feeding and oviposition of the leafminer Liriomyza trifolii. Entomol Exp Appl 65:65-73

Kang JH, Shi F, Jones AD, Marks MD, Howe GA (2010) Distortion of trichome morphology by the hairless mutation of tomato affects leaf surface chemistry. J Exp Bot 61:1053-1064

Khajehali J, Van Nieuwenhuyse P, Demaeght P (2011) Acaricide resistance and resistance mechanisms in Tetranychus urticae populations from rose greenhouses in the Netherlands. Pest Manag Sci 67:1424-1433

Leckie BM, DeJong DM, Mutschler MA (2012) Quantitative trait loci increasing acylsugars in tomato breeding lines and their impacts on silverleaf whiteflies. Mol Breed 30:1621-1634

Liedl BE, Lawson DM, White KK, Shapiro JA, Cohen DE, Carson WG, Trumble JT, Mutschler MA (1995) Acylsugars of wild tomato Lycopersicon pennellii alters settling and reduces oviposition of Bemisia argentifolii (Homoptera: Aleyrodidae). J Econ Entomol 88:742-748

Lucatti AF, van Heusden AW, de Vos RC, Visser RGF, Vosma B (2013) Differences in insect resistance between tomato species endemic to the Galapagos Islands. BMC Evol Biol $13: 175$

Lucini T, Marcos VF, Cristhiane R, Juliano TVR, João RFO (2015) Acylsugar and the role of trichomes in tomato genotypes resistance to Tetranychus urticae. ArthropodPlant Interact 9:45-53

Luckwill LC (1943) The genus Lycopersicon: a historical, biological and taxonomic survey of the wild and cultivated tomatoes. Aberdeen University Press, Aberdeen, p 44

Maharijaya A, Vosman B, Steenhuis-Broers G, Harpenas A, Purwito A, Visser RGF, Voorrips RE (2011) Screening of pepper accessions for resistance against two thrips species (Frankliniella occidentalis and Thrips parvispinus). Euphytica 177:401-410

Maluf WR, Campos GA, Cardoso MG (2001) Relationships between trichome types and spider mite (Tetranychus evansi) repellence in tomatoes with respect to foliar zingiberene contents. Euphytica 121:73-80

Maluf WR, Inoue IF, Ferreira RPD, Gomes LAA, Castro EM, Cardoso MG (2007) Higher glandular trichome density in tomato leaflets and repellence to spider mites. Pesqui Agropecu Bras 42:1227-1235

Muigai SG, Schuster DJ, Snyder JC, Scott JW, Bassett MJ, McAuslane HJ (2002) Mechanisms of resistance in Lycopersicon germplasm to Bemisia argentifolii (Homoptera: Aleyrodidae). Phytoparasitica 30:347-360

Onyambus GK, Maranga RO, Gitonga LM, Knapp M (2011) Host plant resistance among tomato accessions to the spider mite Tetranychus evansi in Kenya. Exp Appl Acarol 54:385-393

Oriani MAD, Vendramim JD, Vasconcelos CJ (2011) No-choice ovipositional nonpreference of Bemisia tabaci (Gennadius) B biotype on tomato genotypes. Sci Agric 68:147-153

Park Y, Lee J (2002) Leaf cell and tissue damage of cucumber caused by two-spotted spider mite (Acari: Tetranychidae). J Econ Entomol 95:952-957

Peralta IE, Spooner DM, Knapp S (2008) Taxonomy of wild tomatoes and their relatives (Solanum sect. Lycopersicoides, sect. Juglandifolium, sect. Lycopersicon; Solanaceae. Syst Bot Monogr 84:1-186

Perdikis D, Kapaxidi E, Papadoulis G (2008) Biological control of insect and mites pests in greenhouse Solanaceous crops. Eur J Plant Sci Biotechnol 2:125-144

Puentes A, Ågren J (2013) Trichome production and variation in young plant resistance to the specialist insect herbivore Plutella xylostella among natural populations of Arabidopsis lyrata. Entomol Exp Appl 149:166-176

Rakha M, Hanson P, Ramasamy S (2015) Identification of resistance to Bemisia tabaci (Genn.) in closely related wild relatives of cultivated tomato based on trichome type analysis and choice and no-choice assays. Genet Resour Crop Evol. doi:10.1007/s10722-015-0347-y

Resende JTV, Maluf WR, Faria MV, Pfann AZ, Nascimento IR (2006) Acylsugars in tomato leaflets confer resistance to the South American tomato pinworm, Tuta absoluta Meyr. Sci Agric 63:20-25

Rick CM (1971) Lycopersicon Mill. In: Wiggins IL, Porter DM (eds) Flora of the Galapagos Islands. Stanford University Press, Stanford, pp 468-471

Rodriguez AE, Tingey WM, Mutschler MA (1993) Acylsugars produced by type-IV trichomes of Lycopersicon pennellii deter settling of the green peach aphid, Myzus persicae. J Econ Entomol 86:34-39

Saeidi Z, Mallik B (2006) In vitro screening of 67 Lycopersicon accessions/cultivars for resistance to two-spotted spider mite. J Biol Sci 6:847-853

Saeidi Z, Mallik B, Kulkarni RS (2007) Inheritance of glandular trichomes and two-spotted spider mite resistance in cross Lycopersicon esculentum 'Nandi' and L. pennellii 'LA2963'. Euphytica 154:231-238

Sances CV, Wyman JA, Ting IP, Van Steerwyle RA, Oatman ER (1981) Spider mite interaction with photosynthesis, transpiration and productivity of strawberry. Environ Entomol 10:442-448

Setter TL, Flannigan BA, Melkonian J (2001) Loss of kernel set due to water deficit and shade in maize: carbohydrate 
supplies, abscisic acid, and cytokinins. Crop Sci 41:1530-1540

Sharma HC, Sujana G, Rao DM (2009) Morphological and chemical components of resistance to pod borer, Helicoverpa armigera in wild relatives of pigeonpea. ArthropodPlant Interact 3:151-161

Sibanda T, Dobson HM, Cooper JF, Manyangarirwa W, Chiimba W (2000) Pest management challenges for smallholder vegetable farmers in Zimbabwe. Crop Prot 19:807-815

Simmons AT, Gurr GM (2005) Trichomes of Lycopersicon species and their hybrids: effects on pests and natural enemies. Agric For Entomol 7:265-276

Snyder JC, Carter CD (1984) Leaf trichomes and resistance of Lycopersicon hirsutum and Lycopersicon esculentum to spider mites. J Am Soc Hortic Sci 109:837-843
Tomczyk A, Kropczynska D (1985) Effects on the host plant. In: Helle W, Sabelis MW (eds) Spider mites, their biology, natural enemies and control. Elsevier, Amsterdam, pp 312-330

Van Haren RJF, Steenhuis MM, Sabelis MW, Deponti OMB (1987) Tomato stem trichomes and dispersal success of Phytoseiulus persimilis relative to its prey Tetranychus urticae. Exp Appl Acarol 3:115-121

Van Leeuwen T, Stillatus V, Tirry L (2004) Genetic analysis and cross-resistance spectrum of a laboratory-selected chlorfenapyr resistant strain of two-spotted spider mite (Acari: Tetranychidae). Exp Appl Acarol 32:249-261 